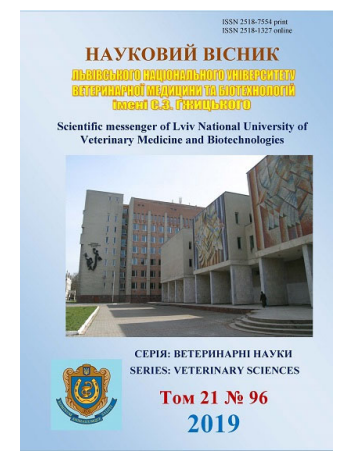

\author{
Науковий вісник Львівського національного університету \\ ветеринарної медицини та біотехнологій імені С.3. Гжицького. \\ Серія: Ветеринарні науки
}
Scientific Messenger of Lviv National University of Veterinary Medicine and Biotechnologies. Series: Veterinary sciences

UDC 619:615:619:98

\title{
Using bacterial preparations of pasteurellosis infection
}

\author{
A.M. Hasanov \\ Article info \\ Received 14.10.2019 \\ Received in revised form \\ 14.11.2019 \\ Accepted 15.11.2019 \\ Veterinary Research Institute of \\ Azeribaijan Republic, \\ 1115, Baku, Azeribaijan Republic \\ Tel.: (+99412) 5624204 \\ E-mail:bav13@meta.ua
}

Veterinary Research Institute of Azeribaijan Republic, Baku, Azeribaijan Republic

\begin{abstract}
Hasanov, A.M. (2019). Using bacterial preparations of pasteurellosis infection. Scientific Messenger of Lviv National University of Veterinary Medicine and Biotechnologies. Series: Veterinary sciences, 21(96), 113-116. doi: 10.32718/nvlvet9620

The using of antibiotics and antimicrobials drugs without control may leads to the development of numerous complications and resistance of microorganisms to antibiotics. The using of antibiotics and antimicrobials drugs should are controlled on farms. That is why the monitoring and determination of sensitivity of bacterial diseases agents to antimicrobial drugs are very important. Results of pasterella, of salmonellas' and kolibakterias' monitoring in farms of Azerbaijan are introduced in the article. The studies were conducted on the basis of the department for quality control of biological preparations of the Azerbaijan Scientific Research Institute. Sampling for microbiological studies was carried out on farms from pathological material and premises where livestock of different age groups are kept. At the same time, the spread of the disease, incidence, mortality, mortality, age-related features, economic losses caused by bacterial pathogens were taken into account. Inoculations from samples of bone, brain, heart, liver, spleen, and lymph nodes were performed on simple and selective and differential diagnostic nutrient media. The results were read visually. Antibiotic sensitivity was determined by agar disco-diffusion method. Microbiological monitoring of a number of farms in Azerbaijan has shown that agents of bacterial diseases' are widely spread. Between the isolated pasterella agent largest number were accounted for Salmonella (54.1\%) and the Escherichia (30.8 per cent). The rest (15.1\%) were isolated cultures of Proteus, Pseudomonas, Klebsiella, Salmonella, Campylobacteria, Enterobacteria, and Clostridia Citrobacter. This indicates that systematic control over the availability of the causative agents of bacterial infections in all critical points of farms is very necessary. Among isolates that were isolated from ill calves and objects, differences in their sensitivity to antimicrobial agents from active substances that officially have registered in our country were discovered. Bactericidal activity of relatively isolated cultures was showed by oxitetraciklin, colistin, ftorfenicol, zeftiocur, doxicyclin, enroxil and sarafloxacin.
\end{abstract}

Key words: calves, bacterial infections, livestock farms, veterinary drugs.

\section{Использование бактериальных препаратов при пастереллезной инфекции}

\author{
Гасанов Азер Мирзасан оглы
}

Азербайджанский ветеринарный научно-исследовательский институт, Баку, Азербайджанская Республика

В статье приведены результаты мониторинга возбудителей бактериальных инфекиий, выделенных у телят, павших от пастереллеза в хозяйствах Азербайджана. Исследования проводились на базе отдела по контролю качества биологических препаратов Азербайджсанского научно-исследовательского института. Отбор проб для микробиологических исследований проводили в хозяйствах из патологического материала и помещений, где содержится скот разных возрастных групп. При этом учитывали распространение болезни, заболеваемость, смертность, летальность, возрастные особенности, экономические убытки, причиненные бактериальными возбудителями. Посевы из проб костного, мозга, сердиа, печени, селезенки, лимфатических узлов проводили на простые и селективные и дифференциально-диагностические питательные среды. Результаты считывали визуально. Чувствительность к антибиотикам определяли диско-диффузным методом в агар. Микробиологический мониторинг животноводческих хозяйств Азербайджана свидетельствует, что возбудители болезней бактериальной этиологии широко распространены. Среди изолированной микрофлоры наряду с пастереллами, наибольшее количество составляли сальмонелль $(54,1 \%)$ и эшерихии (30,8\%). Остальные $(15,1 \%)$ изолированные микроорганизмы - это культуры протея, синегнойной палочки, клебсиелл, иерсиний, 
кампилобактеров, энтеробактерий, циитробактеры и клостридий. Это указывает на необходимость систематического контроля возбудителей бактериальных инфекций в животноводческих хозяйствах. Между изолятами, выделенных от павиих животных, обнаружили различия в их чувствительности к противомикробнылм средствам из числа химиотерапевтических средств, официально зарегистрированных в нашей стране. Бактерицидную активность относительно изолированных культур обнаружил к окситетрациклину, колистину, фторфениколю, иефтиокуру, доксочиклину, энроксилу и сарафлоксацину. На основе полученных данных будет разработана фармако-токсикологическая оченка химиотерапевтических препаратов для профилактики бактериальных инфекиий телят.

Ключевые слова: телята, бактериальные инфекции, животноводческие хозяйства, ветеринарные препаратьл.

\section{Введение}

В научной литературе последнего времени такое сочетание как паразит-хозяин получил название ассоциативного симбиоза, который имеет свои разновидности: мутуализм полезен для обоих партнеров; комменсализм - безвредный для симбионтов и, наконец, антагонизм - варианты вредных последствий для одного из партнеров (Bessarabov et al., 2007; Buhanov et al., 2011; Beljaev \& Beljaeva, 2013; Birjukov, 2015). Колонизация кишечника патогенными микроорганизмами начинается с их связывания с клетками кишечного эпителия. Множество патогенов, включая большинство видов экономически значимых сальмонелл и эшерихий, прикрепляются к кишечнику с помощью рецепторов (фимбрий), специфических к определенным углеводом кишечного эпителия, содержащих монозу, которую они в дальнейшем разрушают и подавляют полезную микрофлору кишечника. Поэтому применение антибиотиков и противомикробных препаратов делает возможным неэффективным лечения многих особо опасных болезней. В то же время бесконтрольное применение антибиотиков и противомикробных препаратов может привести к развитию многочисленных осложнений и к резистентности микроорганизмов к антибиотикам, что побуждает к постоянному контролю их в животноводческих хозяйствах (Volkova, 2009; Vostroilova et al., 2011; Gasanov, 2011). Поэтому очень важным является проведение мониторинга и определения чувствиительности возбудителей бактериальных болезней к антимикробным препаратам (Gerasimov et al., 2015).

Цель работы: определение микроорганизмов из патологического материала телят, павших от пастереллеза, с последующим определением чувствительности микроорганизмов к антибактериальным препаратам.

\section{Материал и методы исследований}

Исследования проводились на базе отдела по контролю качества биологических препаратов Азербайджанского научно-исследовательского института. Отбор проб для микробиологических исследований проводили в хозяйствах из патологического материала и помещений, где содержится скот разных возрастных групп. При этом учитывали распространение болезни, заболеваемость, смертность, летальность, возрастные особенности, экономические убытки, причиненные бактериальными возбудителями. Посевы из проб костного, мозга, сердца, печени, селезенки, лимфатических узлов проводили на простые и селективные и дифференциально-диагностические питательные среды.

Результаты считывали визуально. Чувствительность к антибиотикам определяли диско-диффузным методом в агар.

\section{Результаты и их анализ}

Своими исследованиями мы установили, что у телят, павших от пастереллеза, распространенность от сальмонеллез и эшерихиоз инфекции составляет $84,9 \%$ от общего количества других возбудителей. Процент возбудителей сальмонеллеза - 54,1\%. Надо обратить внимание, что наибольшее количество изолятов относится к серовару S. enteritidis $-16,8 \%$, который вызывает сальмонеллезные токсикоинфекции у человека. Возбудители эшерихиоза выделялись в $30,8 \%$ случаях. Энтеротоксигенный штамм E. coli О157 изолировался в 6,1\% от общего количества эшерихий, а это потенциальный возбудитель эшерихиозной токсикоинфекции (табл. 1).

Это указывает на необходимость систематического контроля за наличием возбудителей бактериальных инфекций во всех животноводческих хозяйствах.

При определении чувствительности изолированных культур к антибактериальным препаратам была установлена высокая резистентность изолированных культур пастерелл и сальмонелл к амоксоцилину, клиндамицину, гентамицину, доксициклину, эгоцину, колистину. Это мы связываем с длительным использованием данных препаратов в животноводческих хозяйствах. Чувствительными культуры были к группе фторхинолонов 3 поколения (энроксилу, цифтиокуру, флорфениколю) и к препаратам комбинированного действия окситетрациклину и сарафлоксацину. Но не было обнаружено препарата, к которому были бы чувствительны все эпизоотически значимые культуры бактерий. Использование таких препаратов приводит к накоплению их в организме телят и продукция от таких животных содержит значительное количество этих препаратов. 
Таблица 1

Мониторинг возбудителей бактериальных инфекций в хозяйствах Азербайджана, \%

\begin{tabular}{|c|c|c|c|c|c|}
\hline $\begin{array}{l}\text { № } \\
\text { П/П }\end{array}$ & $\begin{array}{l}\text { Pasterella }(100 \%) / \\
\text { Salmonella }(54,1 \%)\end{array}$ & $\%$ & $\begin{array}{c}15,1 \% \text { другая } \\
\text { микрофлора }\end{array}$ & $\begin{array}{c}\text { Escherichia coli } \\
(30,8 \%)\end{array}$ & $\%$ \\
\hline 1 & Pasterella multocida & $91,2 \%$ & S. aureus & E. coli $\mathrm{O} 78$ & 10,3 \\
\hline 2 & P. hemolitika & $8,8 \%$ & S. faecalis & E. coli $\mathrm{O} 1$ & 2,1 \\
\hline 3 & S. enteritidis & 16,8 & C. jejuni & E. coli $\mathrm{O} 2$ & 1,8 \\
\hline 4 & S. typhimurium & 10,1 & C. diversus & E. coli $\mathrm{O} 8$ & 1,2 \\
\hline 5 & S. jawa & 10,1 & Y. enterocolitica & E. coli $\mathrm{O} 11$ & 0,6 \\
\hline 6 & S. infantis & 9,1 & P. vulgaris & E. coli $\mathrm{O} 41$ & 0,3 \\
\hline 7 & S. montevideo & 5,2 & E. agglomerans & E. coli $\mathrm{O} 55$ & 2,3 \\
\hline 8 & S. virchow & 1,4 & K. pneumoniae & E. coli $\mathrm{O} 157$ & 6,1 \\
\hline 9 & S. london & 1,0 & P. aeruginosa & E. coli $\mathrm{O} 4$ & 6,1 \\
\hline 10 & S. arizona & 0,4 & & E. coli 035 & 0,1 \\
\hline
\end{tabular}

Таблица 2

Сравнительные результаты чувствительности разных сероваров бактерий к антимикробным препаратам

\begin{tabular}{|c|c|c|c|c|c|c|c|c|c|}
\hline Антибиотики & 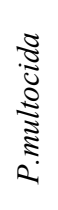 & 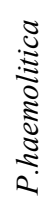 & 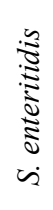 & 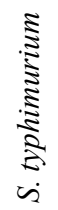 & $\stackrel{0}{\stackrel{0}{\sigma}}$ & 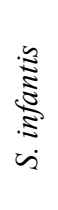 & 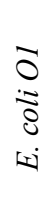 & 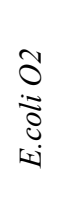 & $\underset{0}{\stackrel{0}{0}}$ \\
\hline Амоксицилин & $\mathrm{p}$ & $\mathrm{p}$ & $\mathrm{p}$ & $\mathrm{p}$ & $\mathrm{p}$ & $\mathrm{p}$ & $\mathrm{p}$ & $\mathrm{p}$ & $\mathrm{p}$ \\
\hline Колистин & $\mathrm{c}$ & $\mathrm{c}$ & $\mathrm{c}$ & $\mathrm{c}$ & $\mathrm{c}$ & $\mathrm{c}$ & $\mathrm{c}$ & $\mathrm{p}$ & $\mathrm{p}$ \\
\hline Флорфениколь & ч & ч & ч & ч & ч & ч & ч & ч & ч \\
\hline Цифтиокур & ч & ч & ч & ч & ч & ч & ч & ч & ч \\
\hline Окситетрациклин & ч & ч & ч & ч & ч & ч & ч & ч & ч \\
\hline Эгоцин & $\mathrm{c}$ & $\mathrm{c}$ & $\mathrm{c}$ & $\mathrm{p}$ & $\mathrm{p}$ & $\mathrm{p}$ & $\mathrm{p}$ & $\mathrm{p}$ & $\mathrm{p}$ \\
\hline Доксициклин & $\mathrm{p}$ & $\mathrm{p}$ & $\mathrm{c}$ & $\mathrm{c}$ & $\mathrm{c}$ & $\mathrm{c}$ & $\mathrm{c}$ & $\mathrm{c}$ & $\mathrm{c}$ \\
\hline Гентамицин & $\mathrm{p}$ & $\mathrm{p}$ & $\mathrm{p}$ & $\mathrm{p}$ & $\mathrm{p}$ & $\mathrm{p}$ & $\mathrm{p}$ & $\mathrm{p}$ & $\mathrm{p}$ \\
\hline Энроксил & ч & ч & ч & Ч & ५ & ч & ५ & ч & ५ \\
\hline Клиндамицин & $\mathrm{p}$ & $\mathrm{p}$ & $\mathrm{p}$ & $\mathrm{p}$ & $\mathrm{p}$ & $\mathrm{p}$ & $\mathrm{p}$ & $\mathrm{p}$ & $\mathrm{p}$ \\
\hline Сарафлоксацин & ч & ч & ч & ч & ч & ч & ч & ч & ч \\
\hline
\end{tabular}

Примечание: ч - чувствительны, с - слабо чувствительны, $\mathrm{p}$ - резистентные

При этом установлено, что они были чувствительны к колистину, фторфениколю, цефтиокуру, окситетрациклину, доксоциклину, энроксилу и сарафлоксацину. Резистентными изолированные культуры эшерихий были к амоксоцилину, клиндамицину, эгоцину, гентамицину. Это также связываем с длительным использованием данных препаратов в хозяйствах. В связи с этим считаем, что с целью профилактики и лечения бактериальных болезней животных необходимо использовать только те препараты, к которым чувствительны не менее $90 \%$ изолированных культур.

При использовании антимикробных средств следует учитывать их побочные действия на организм телят - токсический эффект, аллергическую реакцию, развитие дисбактериозов, возникновения суперинфекции или реакции обострения заболевания. Кроме того, необходимо точно устанавливать дозы препаратов и рассчитывать время их вывода из организма телят, потому что мясо с остатками лекарственных препаратов может вызвать у человека аллергические реакции, дисбактериоз, угнетение иммуногенеза и другие негативные явления.

\section{Вывод}

Микробиологический мониторинг ряда животноводческих хозяйств Азербайджана свидетельствует о том, что у телят, павших от пастереллезной инфекции, возбудители других болезней бактериальной этиологии широко распространены. Среди изолированной микрофлорой наибольшее количество составляли сальмонеллы $(54,1 \%)$ и эшерихии $(30,8 \%)$. Остальные $(15,1 \%)$ изолированные культуры были представлены протеем, синегнойной палочкой, клебсиеллой, иерсинией, кампилобактериями, энтеробактериями, цитробактером и клостридиями. Это указывает на необходимость систематического контроля за наличием возбудителей бактериальных инфекций в телятниках. Среди изолятов, выделенных от павших телят и с объектов, обнаружили различную чувствительность к противомикробным средствам из числа химиотерапевтических средств, официально зарегистрированных в Азербайджане. Бактерицидную активность относительно изолированных культур выявили: колистин, фторфениколь, цефтиокур, окситетрациклин, доксоциклин, энроксил и сарафлоксацин. 


\section{References}

Beljaev, L.I., \& Beljaeva, M.M. (2013). Pravil'nyj podhod $\mathrm{k}$ diagnostike i profilaktike faktornyh infekcionnyh boleznej zhivotnyh. Zh. Veterinarija, 5, 14-16. https://elibrary.ru/item.asp?id=19033248 (in Russian).

Bessarabov, B.F., Voronin, E.S. i dr. (2007). Infekcionnye bolezni zhivotnyh. M.: Kolos (in Russian).

Birjukov, K.N. (2015). Vyzhivaemost' test-organizmov v organicheskih othodah zhivotnovodstva pri uskorennom kompostirovanii. Zh. Veterinarija, 3, 44-45 (in Russian).

Buhanov, V.D., Vezencev, A.I., Ponomareva, N.F. i dr. (2011). Antibakterial'nye svojstva montmorillonit soderzhashhih sorbentov. Nauchnye vedomosti Belgorodskogo gosudarstvennogo universiteta. Belgorod, Serija: Estestvennye nauki, 21(17), 57-62. https://cyberleninka.ru/article/n/antibakterialnyesvoystva-montmorillonit-soderzhaschih-sorbentov (in Russian).

Gasanov, A.M. (2011). Rol' bakterial'nyh associacij pri pasterelleze bujvolov. Zh. Agrarnaja nauka. Moskva, 11, 22-23 (in Russian).

Gerasimov, V.N. i dr. (2015). Biologicheskaja bezopasnost' i biozashhita pri rabote s patogennymi mikroorga-nizmami vo VNIIVViM. Zh. Veterinarija, 1, 4142. https://elibrary.ru/item.asp?id=23057439 (in Russian).

Volkova, E.A. (2009). Kul'tural'nye svojstva jenterobakterij na diagnosticheskih sredah. Zh.Veterinarija, 2, 27-28 (in Russian)

Vostroilova, G.A. i dr. (2011). Antimikrobnaja aktivnost' tilozina. Zh.Veterinarija, 4, 50-51 (in Russian). 